\title{
Mother's Day
}

By Mrs. JOHN HUBBARD, Grenfell, Sask.

It's not often that Mother gets completely away from the family for even two hours but that happened Sunday morning May 16th. Deciding that my face was in too bad a state to display at church I grabbed pencil, notebook and binoculars and calmly announced, "I'm going out for a while".

Must have been my lucky day for at my first stop, the dugout, I saw a male Myrtle Warbler, his insignificant warble in no way living up to the finery of his dress. Tree Swallows danced overhead glinting blue in the sun. I watched closely for the brown dress and breast band of a Bank Swallow but saw none. A horde of little Clay-coloured Sparrows played fly-catcher from branch and fence, darting up and back after insects. A male Blue-winged Teal dropped in to join the company displaying his beautiful spring plumage with pride. Mallards flew back and forth and a Blackbird creaked from a high tree above the water. A Chipping Sparrow sat on the fence long enough to be counted.

I left the dugout and struck out along the lane for the fields. In the grass on the other side of the ditch I saw a small sparrow with a striped head. I couldn't see him well and as the ditch was too broad to jump and too deep to wade I marked him off as just another Clay-coloured and moved on. To prove me right he flew into a tree and horsely sang dee-dee-dee.

Frogs croaked from every spot of water, and two Mallards ascended and descended loudly. Hardly had I got over the shock of their landing noisily in the puddle at my back than they exploded upwards again, to repeat the performance later and in another place.

Two Cowbirds fed in the stubble, waddling awkwardly, then flew off. From a thick bluff I heard the liquid bubbling song of a Redwing but when I turned my glasses on the bird he had a brown head and no red on his wings. Iwas surprised - I had never heard a Cowbird emit anything more than a thin whistle before. This song was like a shorter rendition of the Redwing's.

I passed a small bluff composed of grey-barked poplars standing very straightly against a le a f-strewn slightly sloping bank, their shiny brown buds as yet unopened. And high among the poplars a tall willow bore its catkins.

A pale striped sparrow almost at my feet uttered a faint sweet note drawing my attention as I walked. It had no chestnut shoulder patches yet I was unable to classify it as anything but a Vesper Sparrow. I resolved to watch further and see if perhaps the female does not have this identifying feature.

The big grassy slough was full of noise. Redwings sang, frogs croaked, Mallards quacked, a Coot sneezed in alarm and paddled off more curious than frightened. There was a bulky old Magpie's nest in the willows that fringe the slough but no occupants. A bumble-bee boomed round my head. Willows down and into the water blocked my view and I moved on. 
There was the odd spot of yellow in the dry grass, the first buttercups, and the pearl-like buds of pussytoes hugged the ground.

A noise that in some respects resembles that of a Flicker came from the slough, the call of a Blue-winged Teal. Many other wierd noises came from the slough too and as there was very little there but Coots in quantity I credited them with the noise. I wished for my gloves for the cool wind was outdoing the warm sun.

Birds, bees, and the odd butterfly whizzed quickly by. A rustle in the bush betrayed a young Franklyn ground squirrel and soon the place was alive with incautious youngsters that played like kittens around me.

A Clay-colored Sparrow in some short grass attacked a big black worm, swallowed it with difficulty, cleaned his beak off on a nearby tree branch, and commenced to sing.

A Blackbird chirped from a nearby tree and I turned my glasses idly on it. Now what have we here? Surely from size, beak and voice and striped appearance this should be a female Red-wing. But where did that bright salmon-pink throat and line above eye come from? Back at home, three bird books later, in "Birds of America" I found a description of a female Red-wing that fitted this colourful lady.

Turning towards home I saw some small sandpipers at a flat slough in the stubble. A pair of Baldpates purred from its shallow waters and as I slowly approached as slowly retreated to the other side and waddled out into the stubble. I followed the sandpipers round the slough hoping they would raise their wings or fly up to make identification certain. They refused to enlighten me for some time and then suddenly took to air and disappeared as quickly as only sandpipers can. However, the required clue was given and I marked them down as Pectoral Sandpipers.

Two Horned Larks lit on the black summerfallow some distance away. I was very pleased with my new glasses - even at that distance I could see every detail and colour. There was no yellow on the face or throat of this pair, differing from those I remembered as a youngster on the short grass prairie.

A worn-looking Mourning Cloak flitted by.

Back at the dug-out the Swallows were still at it. A Harris Sparrow was seen and heard, his song as distinctive as his black-faced plumage. I saw several female Myrtle warblers and as I adjusted my binoculars a brilliant green warbler appeared in them for a split second and disappeared forever. "Nothing but an Orange-crowned could be that shade of green", I muttered, but that I was unable to prove.

Reluctantly I turned toward the house and household duties. But it was my lucky day, for that afternoon on a short drive through open prairie country we stopped by a slough to sort out a few ducks. We saw our first pair of Gadwalls of the season, and something else. A small duck, but neither a Blue or Green-winged Teal, or Ruddy. No this almost completely cinnamon red little fellow was nothing else than a Cinnamon Teal, the first we had ever seen tho' we've been on the lookout for such a thing for years. 